\title{
Knowledge of primary care nurses before and after educational intervention on diabetic foot
}

\author{
Conhecimento de enfermeiros da atenção primária antes e \\ após intervenção educativa sobre pé diabético \\ Conocimiento de las enfermeras de atención primaria antes y después \\ de la intervención educativa acerca del pie diabético \\ Lidiany Galdino Felix \\ Ana Elza Oliveira de Mendonça ${ }^{b}$ \\ Isabelle Katherinne Fernandes Costa ${ }^{c}$ \\ Simone Helena dos Santos Oliveira ${ }^{d}$ \\ Ana Maria de Almeida ${ }^{\text {eff }}$ \\ Maria Julia Guimarães Oliveira Soares ${ }^{d}$
}

\begin{abstract}
How to cite this article:
Felix LG, Mendonça AEO, Costa IKF, Oliveira SHS, Almeida AM, Soares MJGO. Knowledge of primary care nurses before and after educational intervention on diabetic foot. Rev Gaúcha Enferm. 2021:42:e20200452. doi: https://doi. org/10.1590/1983-1447.2021.20200452
\end{abstract}

Universidade Federal de Campina Grande (UFCG), Centro de Ciências Biológicas e da Saúde, Unidade Acadêmica de Enfermagem. Campina Grande, Paraíba, Brasil.

b Universidade Federal do Rio Grande do Norte (UFRN), Departamento de Enfermagem. Natal, Rio Grande do Norte, Brasil.

Universidade Federal do Rio Grande do Norte (UFRN), Programa de Pós-graduação em Enfermagem. Natal, Rio Grande do Norte, Brasil.

¿ Universidade Federal da Paraíba (UFPB), Programa de Pós-graduação em Enfermagem. João Pessoa, Paraíba, Brasil.

Universidade Federal da Parába (UFPB). João Pessoa, Paraíba, Brasil.

Universidade de São Paulo (USP), Escola de Enfermagem de Ribeirão Preto. Ribeirão Preto, São Paulo, Brasil.

\section{ABSTRACT}

Objective: To compare the knowledge of the nurses about the diabetic foot before and after the educational intervention.

Method: Quasi-experimental study, before-and-after type, carried out with 53 nurses, from March to June 2016, in the municipality of Campina Grande, Paraiba. The Questioning Methodology was used to develop the educational intervention. Knowledge was investigated using an instrument designed by the researchers. For data analysis before and after the intervention, the McNemar and Wilcoxon tests were performed.

Results: The knowledge of the nurses about the diabetic foot turned out to be deficient, with a mean of correct answers in the pretest of 23.8 (SD \pm 12.8$)$ and after $41.9(S D \pm 9,2)$, with a statistically significant difference $(p<0.01)$.

Conclusion: It was verified a significant increase in the knowledge after the intervention, highlighting the items related to evaluate the loss of plantar protective sensitivity, essential for the prevention of diabetic foot.

Keywords: Diabetic foot. Education, nursing. Primary health care. Public health nursing.

\section{RESUMO}

Objetivo: Comparar o conhecimento de enfermeiros sobre o pé diabético antes e após intervenção educativa.

Método: Estudo quase experimental, do tipo antes e depois, realizado com 53 enfermeiros, de março a junho de 2016, no município de Campina Grande, Paraíba. Foi utilizada a Metodologia da Problematização para o desenvolvimento da intervenção educativa. 0 conhecimento foi investigado por meio de um instrumento delineado pelas pesquisadoras. Para análise dos dados antes e após intervenção, realizaram-se os testes de McNemar e de Wilcoxon.

Resultados: 0 conhecimento dos enfermeiros sobre pé diabético mostrou-se deficiente, com média de acertos no pré-teste de 23,8 $(D P \pm 12,8)$ e após 41,9 (DP $\pm 9,2)$, com diferença estatisticamente significativo $(p<0,01)$

Conclusão: Verificou-se aumento significativo do conhecimento após a intervenção, destacando-se os itens relacionados à avaliação da perda de sensibilidade protetora plantar, fundamentais à prevenção do pé diabético.

Palavras-chave: Pé diabético. Educação em enfermagem. Atenção primária à saúde. Enfermagem em saúde pública.

\section{RESUMEN}

Objetivo: Comparar los conocimientos de las enfermeras sobre el pie diabético antes y después de la intervención educativa.

Método: Estudio cuasi experimental, tipo antes y después, realizado con 53 enfermeros, de marzo a junio de 2016, en el municipio de Campina Grande, Paraíba. Se utilizó la Metodología del Cuestionamiento para desarrollar la intervención educativa. El conocimiento fue investigado mediante un instrumento diseñado por los investigadores. Para el análisis de datos antes y después de la intervención, se realizaron las pruebas de McNemar y Wilcoxon.

Resultados: El conocimiento de las enfermeras sobre el pie diabético resultó ser deficiente, con un promedio de aciertos en el pretest de 23,8 (DE $\pm 12,8)$ y posterior a 41,9 (DE $\pm 9,2)$, con diferencia estadísticamente significativa $(p<0,01)$.

Conclusión: Hubo un aumento significativo en el conocimiento luego de la intervención, destacando las pruebas para evaluar la pérdida de sensibilidad protectora del pie, fundamentales para la prevención del pie diabético.

Palabras clave: Pie diabético. Educación en enfermería. Atención primaria de salud. Enfermería en salud pública. 


\section{口INTRODUCTION}

Diabetic foot is recognized as one of the most recurrent and disabling chronic complications related to Diabetes Mellitus (DM), and encompasses a wide range of changes resulting from neuropathy and peripheral arterial occlusive disease, which can lead to ulceration, infection, osteomyelitis and, consequently, amputation ${ }^{(1)}$.

The growing number of people with diabetic foot portrays a serious global public health problem, with a socioeconomic impact caused by the recurrent need for hospitalizations, non-traumatic lower limb amputations, a significant reduction in quality of life and high mortality ${ }^{(2)}$.

The estimated global prevalence of diabetic foot ulcers in 2017 was 6.4\%, with 13.0\% in North America and 3.0\% in Oceania ${ }^{(3)}$. In the Brazilian scenario, a multicenter study carried out in 2016 found a prevalence of $25.0 \%$ for foot ulcerations and $14.0 \%$ for amputations, occurrences higher than world estimates ${ }^{(4)}$.

In this context, it is essential a shift in the paradigm of care for people with DM, through the implementation of public health policies that prioritize the prevention of ulcers and their recurrence, rather than the treatment of injuries and deformities already installed ${ }^{(1)}$. One of these changes refers to the training of professionals who work in Primary Health Care (PHC) services to manage the factors involved in the etiology of these injuries.

With this understanding, it is highlighted that the clinical examination of the feet should be part of the Nursing consultation for people with DM, whose focus is to identify dermatological, musculoskeletal, vascular and neurological alterations $s^{(5)}$. However, international studies ${ }^{(6-8)}$ have shown that nurses' knowledge on the subject is inadequate. It is also found that the guidelines given to patients and the examination of the feet are not performed satisfactorily by these professionals $s^{(7)}$.

In Brazil, research carried out in the context of PHC also found that the knowledge of nurses is unsatisfactory ${ }^{(9)}$, superficial and fragmented ${ }^{(10)}$, in addition to the fact that actions for the prevention of diabetic foot are limited and the examination of the feet is incompletely performed ${ }^{(11)}$. A review ${ }^{(12)}$ involving the theme highlights the five key elements for the prevention of diabetic foot complications are: (1) diagnosis of the foot at risk for ulceration; (2) regular foot examination; (3) education of patients, family members and health professionals; (4) routine use of appropriate footwear;

(5) treatment of pre-ulcer signs.

In this sense, it is up to the nurse, as a member of the health team, to take co-responsibility for actions to raise awareness and guidance for self-care, changes in lifestyle, systematic assessment of the feet, prevention and treatment of ulcerations ${ }^{(5-8)}$. Insufficient knowledge of these professionals can compromise the quality of care ${ }^{(6-8)}$ and cause mistakes in the provision of care ${ }^{(10)}$, in addition to difficult the correctly track and identification of early complications of diabetic foot among people with DM. Furthermore, in regions where there is no availability of the work of podiatrists and/or specialists with higher education in public health services ${ }^{(1)}$, as is the case in the municipality of Campina Grande in Paraíba, the nurse through specialization and/or training is the one who can perform basic care for the prevention of diabetic foot, especially in PHC services ${ }^{(13)}$.

It is highlighted the scarcity of studies that address educational interventions on diabetic foot for nurses working in PHC. These issues point out to the need for training and investment in Permanent Health Education programs on the subject ${ }^{(6)}$. Given the above and the relevance of the theme, in the public health scenario, it is assumed that an educational intervention promotes increased knowledge of nurses about diabetic foot. Therefore, the objective of this study was to compare the knowledge of nurses about diabetic foot before and after educational intervention.

\section{METHOD}

Intervention study that had characteristics of a quasi-experiment ${ }^{(14)}$, with pre- and post-tests in a single group and was carried out with nurses from the Family Health Strategy (FHS) in the municipality of Campina Grande/Paraíba, from March to June 2016.

For the inclusion of nurses in the study, the following criteria were defined: working in the FHS of the municipality for a minimum period of 12 months and caring for people with DM. Professionals who were on vacation or on sick leave at the time of data collection were excluded.

The research population consisted of all nurses $(n=105)$ who worked in the FHS of that municipality and showed interest in participating in the study, after an invitation by the Municipal Health Department and electronic correspondence. To define the sample size, it was used the formula for research with finite populations, considering a confidence level of $95 \%(\mathrm{Za}=1.96), 5 \%$ sampling error and a population of 105 professionals. The application of the formula resulted in an initial sample of 73 nurses. There was a loss of 20 participants for the following reasons: health problems (4); had a frequency in the course of less than $80.0 \%$ (6); strike of municipal employees (3); did not complete the post-test (7). The final sample consisted of 53 participants.

The study was conducted in three stages: pre-test, intervention, post-test. In the first stage, the profile and prior 
knowledge of nurses was identified, using two instruments. The first consisted of questions about gender, age, time since graduation and professional experience, degree, previous courses on the subject and difficulties to assess the feet of individuals with DM in their professional practice.

The second instrument refers to the "Questionnaire to Investigate the Knowledge of Nurses on Diabetic Foot Questionário de Investigação do Conhecimento de Enfermeiros sobre Pé diabético - QICEPeD", built by the author and previously validated ${ }^{(15)}$ for this research. The content validation process was carried out by ten experts and the analysis of the reliability and internal consistency of the questionnaire was carried out by 14 nurses from the FHS, not included in the sample. The instrument obtained a Content Validity Index $(C V I) \geq 0.90$ and a Cronbach's alpha coefficient ( $a=0.860)$, considered high ${ }^{(15)}$.

The QICEPeD contains 18 items distributed in 12 domains of knowledge on the subject: definition; risk factors; related complications; signs and symptoms of motor and autonomic neuropathy; ulcer prevention; tests to assess loss of protective sensitivity; foot biomechanics and periodicity of assessment according to risk classification. The questionnaire score ranges from zero to 18 points (100\% correct answers). It was considered excellent knowledge being the overall mean of correct answers in the pre- and post-test (> 80\%) and deficient knowledge $(<55 \%)^{(15)}$. The instrument was self-applied, with an average application time of 20 minutes.

The second stage of the research consisted of an educational intervention, carried out by offering a "Theoretical-practical training course on prevention and assessment of diabetic foot", with a total workload of 20 hours. Considering the high number of applicants per health district, the participants were previously allocated into four groups (A, B, C, D). For each group, five face-to-face meetings were held, weekly and lasting four hours. The course was conducted by the researcher, with no professional relationship with the participants.

The educational intervention was carried out according to the stages of the Methodology of Problematization with the Maguerez Arch: Observation of reality, Key Points, Theorization, Solution Hypotheses and Application to reality ${ }^{(16)}$. It is a teaching and research method based on the concept of praxis proposed by Adolfo Sánchez Vázquez, with the liberating pedagogy of Paulo Freire ${ }^{(16)}$. A brief description of the use of this methodology during the educational intervention is presented in Figure 1.

In the third stage of the study, after the end of the intervention, the QICEPeD was applied again in order to verify the effectiveness of the training course in the knowledge of nurses.
For data analysis and organization, the Statistical Package for Social Sciences (SPSS) software version 21.0 was used. Continuous variables were expressed as mean and standard deviation (SD) and categorical variables as absolute and relative frequencies. To compare the differences in the percentage of correct answers in the pre- and post-intervention periods, the McNemar test was used, applied to categorical and dichotomous variables; and the nonparametric Wilcoxon test for variables with asymmetric distribution in the same group. The significance level of $p$-value $(p<0.05)$ was considered for all statistical tests.

All participants signed the Free and Informed Consent Form. The study was approved by the Research Ethics Committee of the Universidade Federal da Paraiba, CAAE 50413915.0.0000.5188.

\section{RESULTS}

53 (100\%) nurses participated in this study, all of which were female. The median age was 41.02 years (SD \pm 9.23$)$, with a minimum age of 23 years and a maximum of 63 years. The average time of work in the PHC was 10.21 (SD \pm 5.40 ) years, with a minimum of one and a maximum of 20 years. The majority $(77.7 \%)$ had a specialization in the area of Public Health. Forty participants (75.5\%) had never taken qualification or training courses on diabetic foot, $83.0 \%(n=44)$ reported having difficulties in assessing the feet of individuals with DM in their professional practice.

From the 18 questions evaluated, 17 (94.4\%) had a correct answer rate of less than $80 \%$ in the pre-test. Only question number six, referring to the domain of prevention of foot ulcers, had a number of correct answers of $88.7 \%$ (excellent knowledge) before the educational intervention. Among the questions with the lowest percentage of correct answers $(<55 \%)$, those numbered 1,5,9, 12 stand out. It is highlighted insufficient knowledge about the issues related to neurological tests to assess Loss of Protective Sensitivity (LPS) (7.2 to 7.4) and to the locations for application of the Semmes-Weinstein monofilament (10g) (8.2 to 9) (Table 1).

After the intervention, there was an increase in the knowledge of nurses in all the questions of the instrument. The questions related to the tests for neurological assessment of the feet $(7,8,9$ and 10$)$ showed a statistically significant correct answers rate $(p<0.001)$ in the post-test. The domain that had the lowest rate of correct answers was item 12, which refers to the frequency of assessment of feet with risk classification. The overall mean of correct answers in the post-test $(M D=41.9 ; S D \pm 9.2)$, comparatively, was significantly $(p<0.01)$ higher than in the pre-test $(\mathrm{MD}=23.8 ; \mathrm{SD} \pm 12.8)$. 


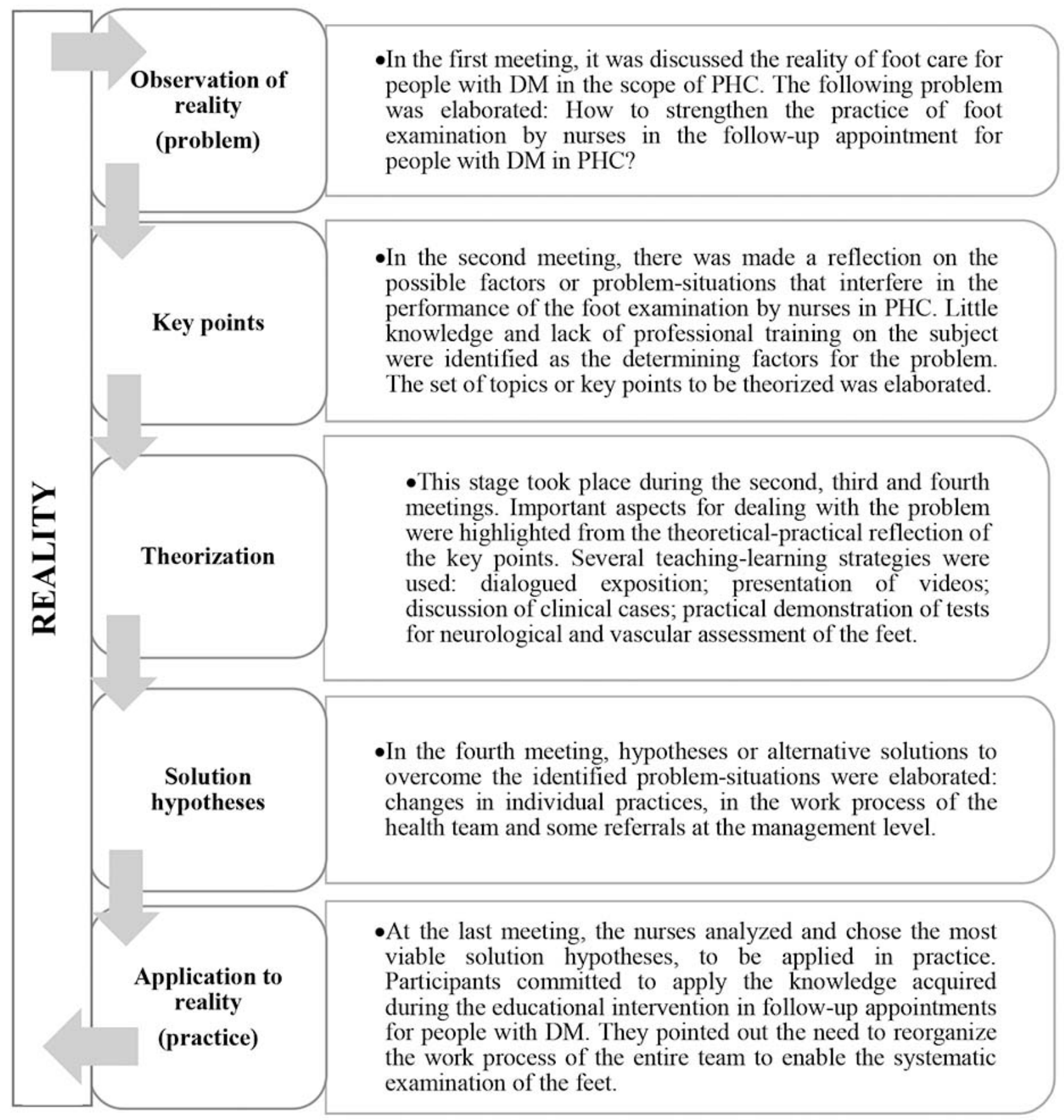

Figure 1 - Description of the use of the Methodology of Problematization in educational intervention on diabetic foot for PHC nurses. Campina Grande, Paraíba, Brazil, 2016

Source: Research data, 2016.

\section{DISCUSSION}

Regarding the self-assessment of nurses' knowledge, most stated that they had difficulties in assessing the feet of people with DM in their professional practice, consistent with the high percentage of participants who revealed that they had never received prior training on the subject and with the low percentage of correct answers ( $<55 \%$ ) observed in the pre-test, for questions 7 to 12 , related to the LPS assessment.

The lack of technical and scientific training on diabetic foot was also portrayed by international| ${ }^{(6-8)}$ and national ${ }^{(9-11)}$ research. The results described in the present study highlight 
Table 1 - Number of correct answers on questions related to the knowledge of nurses on diabetic foot, before and after the intervention. Campina Grande, Paraíba, Brazil, 2016. (n=53)

\begin{tabular}{|c|c|c|c|}
\hline Items & Before n(\%) & After $n(\%)$ & p-value* \\
\hline 1. Definition of diabetic foot & $26(49.1)$ & $41(77.4)$ & 0.003 \\
\hline 2. Risk factors for diabetic foot & $42(79.2)$ & $44(83.0)$ & 0.804 \\
\hline 3. Complications of the diabetic foot & $32(60.4)$ & $37(69.8)$ & 0.332 \\
\hline 4. Signs of symptoms of motor neuropathy & $29(54.7)$ & $35(66.0)$ & 0.327 \\
\hline 5. Signs and symptoms of autonomic neuropathy & $11(20.8)$ & $35(66.0)$ & $<0.001$ \\
\hline 6. Prevention of diabetic foot ulcers & $47(88.7)$ & $48(90.6)$ & 1 \\
\hline \multicolumn{4}{|l|}{ 7. Loss of protective sensitivity of the foot at risk } \\
\hline 7.1 Test with $10 \mathrm{~g}$ monofilament & $38(71.7)$ & $53(100)$ & $<0.001$ \\
\hline 7.2 Test with $128 \mathrm{~Hz}$ tuning fork & $6(11.3)$ & $39(73.6)$ & $<0.001$ \\
\hline 7.3 Test for sting sensation & $18(34.0)$ & $35(66.0)$ & 0.002 \\
\hline 7.4 Hammer test for Achilles tendon reflex & $9(17.0)$ & $34(64.2)$ & $<0.001$ \\
\hline \multicolumn{4}{|l|}{$\begin{array}{l}\text { 8. Application sites of the } \\
\text { Semmes-Weinstein monofilament }\end{array}$} \\
\hline 8.1 Hallux & $30(56.6)$ & $51(96.2)$ & $<0.001$ \\
\hline 8.2 First metatarsal & $22(41.5)$ & $50(94.3)$ & $<0.001$ \\
\hline 8.3 Third metatarsal & $6(11.3)$ & $50(94.3)$ & $<0.001$ \\
\hline 8.4 Fifth metatarsal & $17(32.1)$ & $50(94.3)$ & $<0.001$ \\
\hline 9. Recommended number of test applications & $13(24.5)$ & $46(86.8)$ & $<0.001$ \\
\hline $\begin{array}{l}\text { 10. Interpretation of tests to assess loss of } \\
\text { protective sensitivity }\end{array}$ & $32(60.4)$ & $47(88.7)$ & 0.001 \\
\hline 11. Assessment of the biomechanics of the feet & $38(71.7)$ & $44(83.0)$ & 0.238 \\
\hline $\begin{array}{l}\text { 12. Frequency of assessment of the feet according to } \\
\text { the risk classification }\end{array}$ & $13(24.5)$ & $15(28.3)$ & 0.824 \\
\hline
\end{tabular}

*McNemar test for paired samples.

Source: Research questionnaire applied in the study.

that PHC nurses need to receive training to correctly assess the feet of people with DM and suggest that actions to prevention and assessment of diabetic foot are not being carried out in accordance with international recommendations $s^{(12-13)}$, which can compromise the quality of care provided ${ }^{(8,10)}$.
The neurological examination of the feet of people with DM comprises the assessment of sensitivity (tactile, painful-thermal and vibratory), tendon reflexes and motor function ${ }^{(1,12-13)}$. Its main objective is to identify LSP, for risk classification and prevention of ulcerations ${ }^{(1)}$. It is 
recommended ${ }^{(12-13)}$ that this exam should be performed using the Semmes-Weinstein monofilament (10g), associated with one more test between: $128 \mathrm{~Hz}$ tuning fork (vibrating sensitivity); neurological hammer (Achilles tendon reflex); pin or disposable toothpick (painful sensitivity).

In the analysis of the items on LSP assessment, it is highlighted that the worst pre-test scores were found in items 7.2 Tests with $128 \mathrm{~Hz}$ tuning fork (11.3\%), 7.3 Test for sting sensation (34\%), and 7.4 Hammer test for Achilles tendon reflex $(17 \%)$, while higher scores were observed for item number 7.1 Test with $10 \mathrm{~g}$ monofilament (71.7\%). A research carried out in another state in Northeastern Brazi ${ }^{(9)}$, found similar data regarding the satisfactory knowledge of nurses about the use of monofilament.

After the educational intervention, there was a statistically significant percentage of correct answers for questions 7 to 10 , with emphasis on all nurses who answered correctly to item 7.1. As well, there was an increase in the number of participants who correctly identified the sites to apply the monofilament. It is worth noting that, throughout the theorizing stage, the practical demonstration of tests for screening LSP and vascular assessment was performed, according to international guidelines ${ }^{(12-13)}$.

It is noteworthy that during the educational intervention, most nurses stated they did not have all the equipment recommended to perform the systematic assessment of the diabetic foot, especially the tuning fork and reflex hammer. In health units that had the monofilament, this was intended only for the leprosy screening program. Although the PHC services in the investigated municipality do not have the tuning fork and hammer, these instruments were included in the questionnaire to investigate knowledge of nurses, as they are recommended by the Ministry of Health and by current guidelines ${ }^{(12-13)}$ for the early detection of ulcerative processes in the feet, associated with decreased vibratory sensation and ankle areflexia ${ }^{(12)}$.

National research ${ }^{(9-10)}$ also report that PHC services do not have the necessary instruments to perform a complete foot examination. In addition, most nurses are unaware of the basic materials for this assessment and perform the exam inappropriately, adapting other materials such as a key, pencil, line ${ }^{(10)}$, ballpoint pen, stylus and a glass of water ${ }^{(9)}$. It should be noted that the use of these materials, instead of monofilament, should be discouraged as they are not capable of detecting changes in sensitivity in the feet, in contrast to recommendations based on scientific evidence $e^{(1,12-13)}$.

Thus, the results of the aforementioned studies are extremely worrying, point out to the precariousness of equipment to implement this care in PHC and reinforce the need for qualification and updating of these professionals, to correct mistaken practices that can compromise the screening of the foot at risk of ulceration. As actions aimed at controlling DM in PHC are the responsibility of the municipal health management, it is considered essential to regularly supply and maintain the regular equipment needed to carry out actions aimed at the prevention of diabetic foot ${ }^{(17)}$.

In the absence of the recommended instruments for screening the LSP, it is recommended ${ }^{(12-13)}$ that the Ipswich Touch Test be performed, also called the toe touch test, considered simple and easy to apply, which does not require equipment to your achievement. This showed good agreement and efficacy for screening of peripheral neuropathy and identifying the risk of ulceration compared to the $10 \mathrm{~g}$ monofilament ${ }^{(18)}$. In addition, it can be widely performed in PHC services by any trained healthcare professional. During this test, the examiner lightly touches the hallux, third and fifth toes of each foot of the person with DM, for two seconds. If there is sensitivity in five or six touches performed, the test is considered normal ${ }^{(13,18)}$.

According to international guideline ${ }^{(13)}$ all people diagnosed with DM must have their feet periodically examined by higher-level qualified health professionals, preferably by the PHC physician and/or nurse, according to the ulceration risk stratification system. The frequency of follow-up should be increased from the identification of LSP or peripheral arterial disease, considering the degree of risk of each person ${ }^{(12-13)}$.

It stood out the high (>80\%) percentage of correct answers for item 6 Prevention of foot ulcers, before and after the educational intervention. A similar study carried out in Turkey ${ }^{(7)}$ also obtained a high level of knowledge regarding diabetic foot ulcers. However, the same study found that $80.9 \%$ of nurses did not adequately advise patients about the risk or problems related to the diabetic foot, nor did they perform the foot examination.

Several studies ${ }^{(5,1)}$ demonstrate the little knowledge of people with diabetes about care for the prevention of diabetic foot and the failures in the guidance offered by PHC nurses ${ }^{(5,7-11,19)}$. In addition, effective practices for the prevention of diabetic foot are limited to health education actions and not to foot examination ${ }^{(11,19)}$. Such finding is in line with another study carried out in an outpatient clinic in the city of São Paulo ${ }^{(5)}$ which found that most individuals with DM, coming from the PHC, never had their feet examined with the monofilament, nor received guidance from a professional of the health on practices for self-care with the feet.

It is noteworthy that examining the feet of people with DM is a key element for the prevention of ulcerations and complications associated with the disease $\mathrm{e}^{(1,5,7,12-13)}$. The PHC 
nurse plays an important role in this care ${ }^{(5-11,18)}$, and should become familiar with and incorporate it into their care practice ${ }^{(5)}$. The nursing consultation and the home visit are favorable moments to carry out this assessment, classify the risk of ulceration, identify the individual's ability to take care of themselves, propose preventive actions and guide them about self-care, considering individual characteristics, their family support network and the context in which they live ${ }^{(19)}$.

A retrospective longitudinal study ${ }^{(20)}$, carried out in a hospital in Rio Grande do Sul found the efficiency of a follow-up program, conducted by nurse educators, as a protective factor against mortality among patients with type $2 \mathrm{DM}(\mathrm{p}<0.001)$. The authors highlighted that patients who maintained this regular follow-up for ten years, received self-care guidelines and underwent regular foot examinations by nurses, lived longer, due to the reduction in the risks that affect complications related to the diabetic foot ${ }^{(20)}$.

It is believed that only when the systematic assessment of the feet for screening of LSP is incorporated by the FHS teams, as a routine care practice for people with DM, there will be a reduction in the number of ulcers and, consequently, of lower limb amputations resulting from the diabetic foot in the country. When elaborating the solutions hypotheses for coping with the identified problems, the nurses considered essential the need for management support to continue the discussions started during the educational intervention, and to create adequate conditions, through the continuous supply of necessary equipment for these professionals so they can perform the neurological assessment in PHC services, effectively and efficiently. Even with training, the absence of these supplies can compromise the clinical practice of professionals and the continuity of care for the diabetic foot. It is also expected that the management organizes access flows to ensure comprehensive care at all points in the network and performs systematic monitoring and evaluation of the offered actions ${ }^{(17)}$.

By analyzing the overall mean of correct answers before and after the test, it was found that the educational intervention based on the Methodology of Problematization ${ }^{(16)}$ provided a significant increase $(p<0.01)$ in the knowledge of nurses. From the 18 items evaluated by the QICEPeD, ten (55.5\%) achieved correctness rates above $80 \%$, considered excellent ${ }^{(13)}$, after the intervention.

Thus, the present study confirms the importance of updating PHC knowledge of nurses on diabetic foot, through PHE actions that use active methodologies, capable of integrating theory and practice, as a way of transforming reality, taken as the focus of the study. The literature ${ }^{(6-8)}$ emphasizes that trained nurses are able to act, safely and effectively, in the prevention of diabetic foot complications.

\section{CONCLUSION}

The study managed to achieve the proposed objective. There was a significant difference in the knowledge of nurses after the intervention, highlighting the items related to the LSP assessment. The instrument used is suitable for measuring the knowledge of PHC nurses about diabetic foot, which allows its reproducibility in further studies.

It was found, in the pre-test, that most participants had deficient knowledge on the subject. These results reiterate the need to continue the process of qualification in service and the inclusion of the subject in PHE programs.

Among the limitations of this study, stand out the sample size, the absence of control group and the immediate posttest, which can compromise the generalization of the results in different contexts. Longitudinal studies are suggested to evaluate changes in care practices and the impact of this intervention on the prevention of lower limb ulcers and amputations.

The study advances in knowledge when it demonstrates that the Methodology of Problematization with the Arch of Maguerez can be used as a possible methodological path to be applied in PHE programs, by articulating theory and practice and stimulating the action and reflection of nurses throughout the teaching-learning process. The use of this methodology in the present study contributed to understanding the reality of care for the prevention and assessment of diabetic foot performed by the PHC nurses, problematizing it and intervening in it in search of solutions aimed at enabling the systematic examination of the feet and transforming the investigated reality.

It is expected that the data presented in this study can be used by managers, researchers, professors, and researchers in planning teaching-learning actions such as courses, training and seminars on the subject aimed at nurses working in PHC.

\section{REFERENCES}

1. Armstrong DG, Boulton AJM, BuS SA. Diabetic foot ulcers and their recurrence. N Engl J Med. 2017;376(24):2367-75. doi: https://doi.org/10.1056/ NEJMra1615439

2. Lazzarini PA, Pacella RE, Armstrong DG, van Netten JJ. Diabetes-related lowerextremity complications are a leading cause of the global burden of disability [letter]. Diabet Med. 2018:35:1297-9. doi: https://doi.org/10.1111/dme.13680

3. Zhang P, Lu J, Jing Y, Tang S, Zhu D, Bi Y. Global epidemiology of diabetic foot ulceration: a systematic review and meta-analysis. Ann Med. 2017;49(2):106-16. doi: https://doi.org/10.1080/07853890.2016.1231932

4. Parisi MC, Moura Neto A, Menezes FH, Gomes MB, Teixeira RM, de Oliveira JE, et al. Baseline characteristics and risk factors for ulcer, amputation and severe neuropathy in diabetic foot at risk: the BRAZUPA study. Diabetol Metab Syndr. 2016;8:25. doi: https://doi.org/10.1186/s13098-016-0126-8 
5. Lucoveis MLS, Gamba MA, Paula MAB, Morita ABPS. Degree of risk for foot ulcer due to diabetes: nursing assessment. Rev Bras Enferm. 2018;71(6):3041-7. doi: http://doi.org/10.1590/0034-7167-2017-0189

6. AbdullahWH,Al-Senany S,Al-Otheimin HK. Capacity building for nurses'knowledge and practice regarding prevention of diabetic foot complications. Int J Nurs Sci. 2017 [cited 2019 May 10];7(1):1-15. Available from: https://www.researchgate. net/publication/317560459_Capacity_Building_for_Nurses_Knowledge_and_ Practice_Regarding_Prevention_of_Diabetic_Foot_Complications

7. Kaya Z, Karaca A. Evaluation of nurses' knowledge levels of diabetic foot care management. Nurs Res Pract. 2018:8549567. doi: https://doi. org/10.1155/2018/8549567

8. Kumarasinghe SA, Hettiarachchi P,Wasalathanthri S. Nurses'knowledge on diabetic foot ulcer disease and their attitudes towards patients affected: a cross-sectional institution-based study. J Clin Nurs. 2018;27(1-2):e203-e212. doi: https://doi. org/10.1111/jocn.13917

9. Arruda LSNS, Fernandes CRS, Freitas RWJF, Machado ALG, Lima LHO, Silva ARV. Nurse's knowledge about caring for diabetic foot. J Nurs UFPE on line. 2019;13:e242175. doi: https://doi.org/10.5205/1981-8963.2019.242175

10. Vargas CP, Lima DKS, Silva DL, Schoeller SD, Vragas MAO, Lopes SGR. Conduct of primary care nurses in the care of people with diabetic foot. J Nurs UFPE on line. 2017 [cited 2019 May 10]; 11(Supl. 11):4535-45. Available from: https:// periodicos.ufpe.br/revistas/revistaenfermagem/article/viewFile/231192/25180

11. Pereira LF, Paiva FAP, Silva SA, Sanches RS, Lima RS, Fava SMCL. Nurse's actions in diabetic foot prevention: the perspective of the person with diabetes mellitus. Rev Fun Care Online. 2017;9(4):1008-14. doi: https://doi.org/10.9789/21755361.2017.v9i4.1008-1014

12. van Netten JJ, RaspovicA, Lavery LA, Monteiro-Soares M, Rasmussen A, Sacco ICN, et al. Prevention of foot ulcers in the at-risk patient with diabetes: a systematic review. Diabetes Metab Res Rev. 2020;36(S1):e3270. doi:https://doi.org/10.1002/dmrr.3270
13. Schaper NC, van Netten JJ, Apelqvist J, Bus SA, Hinchliffe RJ, Lipsky BA, et al. Practical guidelines on the prevention and management of diabetic foot disease (IWGDF 2019 update). Diabetes Metab Res Rev. 2020;36(S1):e3266. doi: https:// doi.org/10.1002/dmrr.3266

14. Polit DF, Beck CT. Fundamentos de pesquisa em enfermagem: avaliação de evidências para a prática da enfermagem. 9. ed. Porto Alegre: Artmed; 2019.

15. Felix LG. Intervenção educativa sobre pé diabético para enfermeiros da atenção primária [Tese]. João Pessoa: Universidade Federal da Paraíba; 2017 [cited 2019 May 10]. Available from: https://repositorio.ufpb.br/jspui/ bitstream/123456789/12329/1/Arquivototal.pdf

16. Berbel NAN, Gamboa SAS. A metodologia da problematização com o Arco de Maguerez: uma perspectiva teórica e epistemológica. Filos Educ. 2011 [cited 2019 May 10];3(2):265-87. Available from: https://www.researchgate.net/ publication/326661630_A_metodologia_da_problematizacao_com_0_Arco_ de_Maguerez_uma_perspectiva_teorica_e_epistemologica

17. Borges DB, Lacerda JT. Actions aimed at the Diabetes Mellitus control in primary health care: a proposal of evaluative model. Saúde Debate. 2018;42(116):162-78. doi: https://doi.org/10.1590/0103-1104201811613

18. Dutra LMA, Moura MC, Prado FA, Lima GO, Melo MC, Fernandez RNM, et al. Is it possible to substitute the monofilament test for the Ipswich Touch Test in screening for peripheral diabetic neuropathy? Diabetol Metab Syndr. 2020;12:27. doi: https://doi.org/10.1186/s13098-020-00534-2

19. Silva JMTS, Haddad MCFL, Rossaneis MA, Vannuchi MTO, Marcon SS. Factors associated with foot ulceration of people with diabetes mellitus living in rural areas. Rev Gaúcha Enferm. 2017;38(3):e68767. doi: https://doi. org/10.1590/1983-1447.2017.03.68767

20. Scain SF, Franzen E, HirakataVN. Effects of nursing care on patients in an educational program for prevention of diabetic foot. Rev Gaúcha Enferm. 2018;39:e20170230. doi: https://doi.org/10.1590/1983-1447.2018.20170230 


\section{- Authorship contribution:}

Conceptualization: Lidiany Galdino Felix, Simone

Helena dos Santos Oliveira, Maria Julia Guimarães

Oliveira Soares.

Investigation: Lidiany Galdino Felix, Maria Julia

Guimarães Oliveira Soares.

Methodology: Lidiany Galdino Felix, Isabelle Katherinne

Fernandes Costa, Simone Helena dos Santos Oliveira,

Maria Julia Guimarães Oliveira Soares.

Writing-original draft, Writing-review \& editing: Lidiany

Galdino Felix, Ana Elza Oliveira de Mendonça, Isabelle

Katherinne Fernandes Costa, Simone Helena dos

Santos Oliveira, Ana Maria de Almeida, Maria Julia

Guimarães Oliveira Soares.

The authors declare that there is no conflict of interest.

\section{- Corresponding author:}

Lidiany Galdino Felix

E-mail: lidigaldinofelix@gmail.com

\section{Associate editor:}

Carlise Rigon Dalla Nora 